\title{
TTF

\section{The impact of the four motivation boosters on tennis player development (part 2)}

\section{Antoni Girod (FRA)}

ITF Coaching and Sport Science Review 2015; 67 (23): 25 - 26

\section{ABSTRACT}

This article is a continuation of the first part. In this part, we will discuss the last two motivation-related concepts for the long-term development of tennis players.
Key words: Development, long term, Development, long term, psychology, progress

Received: 26 April 2015

Accepted: 16 July 2015

Corresponding author:

Caroline Martin

Email: agirod@halifax.fr

\section{INTRODUCTION}

The "Progress" booster

Now that we know that the first two motivation boosters, i.e. Meaning and Enjoyment, are key to the success of the learning process in its early stages or that they can help a player regroup for a fresh start, let's take a look at the third booster, i.e. Progress, which is essential to maintain motivation in the long run. This specific concept cannot be separated from the notions of work and discipline, as illustrated by Kei Nishikori's words: "When I was 12, I was selected for a three-week trial at Bollettieri's tennis academy. I immediately loved it. I would play tennis all day and even if it was hard work, the pro players who were training there showed me that you had to work really hard to become a professional player." Gabe Jaramillo, head coach at Bollettieri's, recalls: "Many teenagers that come to the Academy have a lot of talent, but many of them also don't work hard enough to achieve their full potential. Right from the very first day, things were different with Kei. If we'd tell him to arrive at 7 in the morning for a training session, he'd be there at 6:45 with his rackets ready and his tennis shoes firmly tied. At 7 am sharp, he'd be ready to start training." Discipline, an essential value for anyone who wishes to reach the highest level, needs to be instilled in players by their coach between the ages of 10 and 12.

The goal is for the player to be able to discipline himself, so that he does not need to rely on others to push himself to progress. Stanislas Wawrinka, one of the hardest workers on the ATP Tour, had a difficult start to the 2013 season. This is what Severin Lüthi, captain of the Swiss Davis Cup team, said on the subject: "Stan suffered some difficult losses early this year, but we always said: 'Look, the most important thing is what you make of this situation. If you react negatively and bury yourself in a hole, you won't make any progress. You need to accept the positives and negatives, and learn from them to improve. That is all you can do.' And through self- discipline, that's exactly what he's managed to do." In the spring of that year, the Swiss player arrived at the Monte-Carlo Masters Series tournament with a Samuel Beckett quote tattooed on his inner left forearm: "Ever tried. Ever failed. No matter. Try again. Fail again. Fail better." Here's what the Swiss player had to say about it: "It's my second tattoo; I'd been thinking of doing it for a while. It's a quote that I really like because it sums up well my job and my desire to always try despite the defeats." You could call it having the Progress booster under the skin!
Rafael Nadal knows better than anyone else the importance of switching to another booster when the others do not work. In 2011, after a loss to Tsonga at the ATP World Tour Finals in London, here's how the Majorcan player analysed the situation: "I did not play well. My game in the third set was a disaster. But well... You have to accept it and get back to work. I probably have a little less passion for the game at the moment because I'm tired. The season has been tough despite positive things and I have to accept it and learn from it to be ready for the start of next season. In a career, there are ups and downs. My motivation is still there and I'll do my best to come back. Each day, I will try to improve something in my game. If in the end it's not enough, I'll have no regrets and I'll be proud of myself." Getting back to work and focusing on the Progress booster when results are not happening or there is less enjoyment is the Spanish champion's way of solving the problem. However, it is also essential to focus on that Progress booster in times of good performance and not only when results are poor. Evidence of this are Sam Sumyk's words, talking about Victoria Azarenka during her amazing run of successive wins in 2012: "After a difficult win in her first match at Indian Wells, we had a little talk and we realised that we were taking things too much for granted. Like if she'd miss a shot in training, we'd go: 'Well, no big deal.' After that, she started working twice as hard. And there hasn't been a moment of sloppiness since."

\section{THE "PERFORMANCE" BOOSTER}

In today's society, the cult of performance is everywhere. Only victory matters. Pierre de Coubertin's initial idea that participation is more important than winning ('L'important c'est de participer") has since been replaced with the Olympic motto "Citius, Altius, Fortius" ("Faster, Higher, Stronger"). This threeword expression uses a comparative form with no second part. As is often stated, "nature abhors a vacuum"; therefore, to the following question: "Faster, higher, stronger than whom?", it would seem that the answer is: "Faster, higher, stronger than the others." Because the idea here is indeed to prevail over, dominate, defeat, or, to use a more warrior- like expression, to "kill" your opponent. This cult of excellence at any price which glorifies the ultimate winner, the individual who reaches the top, means at the same time that all the others, i.e. the losers, are not worth much. For better or for worse, the fact is that competitive sport is based on a "winner-loser" system. Can the quest for performance be accomplished only in this context? Is it not possible to think of an alternative vision of competition 
where interpersonal relationships would be based on a "winner-winner" scenario? What if the answer to the question: "Faster, higher, stronger than whom?" was: "Faster, higher, stronger than myself?" What if the quest for excellence, rather than being about comparing oneself to others was about comparing oneself to oneself; what if it was about a constant search for improvement without demeaning others or feeling demeaned by others' performance? The opponent, far from being the enemy, becomes an individual that helps you reveal your hidden potential and become aware of your strengths and areas for improvement.

In an interview given a few years ago after a loss to Federer, Andre Agassi, then still an active player, had the following to say to a journalist who was asking him about his possible retirement: "As long as I see that my opponents have to raise the level of their game to near perfection against me to be able to win, as long as I have opponents like Federer who force me to dig deep to raise my level of play, and that I'm physically able to play, win or lose, l'll keep playing."

For Agassi, the purpose of competition was for both players to emerge stronger from the contest. In other words, regardless of the outcome, the more my opponent makes it hard for me, the more he forces me to improve. Similarly, the more I make my opponent's life difficult, the more I make him progress. The purpose of a tennis match is no longer to win, but to improve and make my opponent improve. As a result, when both players come out of the court after their match, there is no longer a winner and a loser, but two winners and one victor. This year, at the French Open, there wasn't one winner and 127 losers, but rather 127 winners and one victor!

Many players who go through a period without any significant results use the strategy of small victories. To do this, they put their ego aside and humbly choose to compete in smaller tournaments. This is precisely what Benoit Paire did when, after dropping to 135 in the rankings in January of this year, he decided to play in Bressuire, a Futures tournament: "It's tough to drop in the rankings when you've been as high as number 24. It's not easy mentally, but I have to accept this situation. I'll do whatever it takes to get back to my best level. That's why I'm here. The goal this week is to play as many matches as possible, have good training sessions and see if my knee holds up! I'm here to win matches and why not go all the way to start my season on a positive note. But I also know that I might lose in the first round." After winning this Futures tournament, he went on to play 3 challenger events, winning two of those and finishing as the finalist in the third. Thanks to this strategy of small victories, he was able to get back to the top 100 by early April but, most of all, he was able to gradually rebuild his confidence.

\section{CONCLUSION}

The secret behind constant motivation: combining the four boosters

Now aged over 30, where does Serena Williams get her motivation from? Here's how the player with the most singles and doubles titles in the history of Grand Slam tennis explains it: "I love playing tennis and I love winning. What keeps me going is the fact that I'm healthy and that I win. When things are going this way, I simply want to maintain this momentum, and keep on progressing and trying to win. But if I lose, what keeps me going is something totally different: I then want to find out why I lost and what I can improve and if I'm still able to do it." In two sentences, Serena Williams combines three of the four boosters. First, the Enjoyment booster: "I love playing tennis"; second, the Performance booster: "What keeps me going is the fact that I win"; third, the Progress booster: "I want to keep on progressing; I want to find out what I can improve". Later, the American player adds: "Before when I was winning, I would win one, two, three or four Major titles whereas now, one Grand Slam trophy means a lot more to me. It has more meaning in the history of the game." The only booster left to explain how this amazing champion managed to maintain her motivation was the fourth and final one, i.e. the Meaning booster: during her career, she was able to combine the four motivation boosters through constant determination. And that is the reason why she has become a role model for many aspiring players.

\section{REFERENCES}

Girod, A. (2005). Tennis and neuro-linguistic programming, ITF Coaching and Sport Science Review, 37, 11-12.

Girod, A. (2010). Comprendre et pratiquer la PNL. Dunod Editeur.

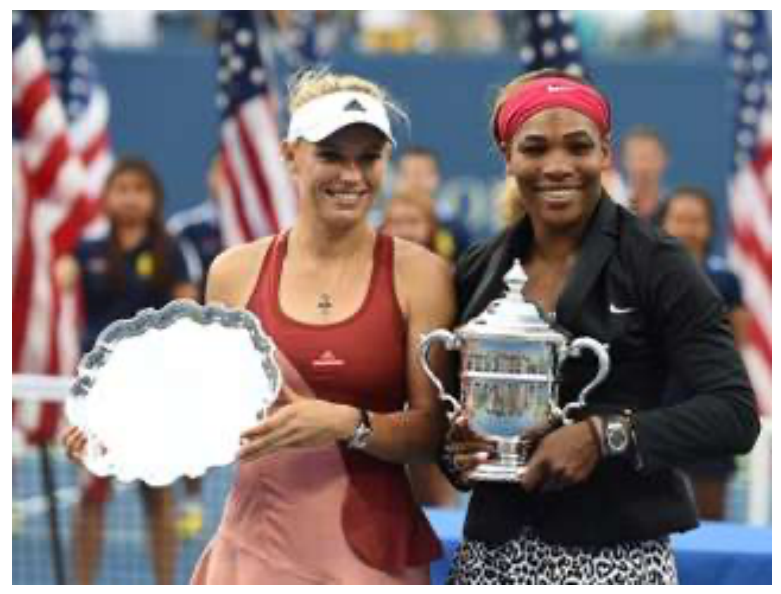

RECOMMENDED ITF TENNIS ACADEMY CONTENT (CLICK BELOW)

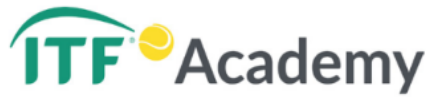

Copyright (c) Antoni Girod 2015

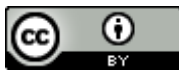

This text is under a Creative Commons BY 4.0 license

You are free to Share - copy and redistribute the material in any medium or format - and Adapt the content - remix, transform, and build upon the material for any purpose, even commercially under the following terms:

Attribution: You must give appropriate credit, provide a link to the license, and indicate if changes were made. You may do so in any reasonable manner, but not in any way that suggests the licensor endorses you or your use.

CC BY 4.0 license terms summary $\quad$ CC BY 4.0 license terms 